\title{
On the Intrinsic Value and Realization Way of the Constitution Construction of Private Colleges and Universities
}

\author{
Guicheng $\mathrm{Hu}$ \\ E-commerce School of Wuhan Technology and Business University, Wuhan, China \\ 14987620@qq.com
}

Keywords: Constitution of private colleges and universities Intrinsic value; Realization way

\begin{abstract}
The university constitution is the basis of the rule of law for the running of private colleges and universities in accordance with the law and is also an important medium to construct a modern university system, as well as the main way to ensure a university's independent running, and the solid backing for the private colleges and universities to strengthen their external exchange and cooperation. Because the private colleges and universities are more complicated and diverse than the public colleges and universities in the mode of running school and the management ideas, it may lead to the vagueness of the main body of the constitution drafting, the excessive commonness but lacking of individuality in the constitution, and poor implementation effect of the constitution, the existence of formalism or other problems. Then, it is urgent to clarify the responsibility subject of the constitution; and the realization way needs to be proposed from three aspects, such as digging its own characteristic and cultural idea, building an individualized constitution, strengthening the examination and supervision on the contents of the constitution, so as to ensure the scientificity, comprehensiveness, systematicness, rationality and validity of the constitution construction of the private colleges and universities.

The constitution of colleges and universities is the main body of modern university system, and also is a necessary criterion for colleges and universities to run school independently and carry out public affairs management, a basis for them to carry out teaching activities and social practice activities and a strong guarantee for them to systematically construct a modern university system. Therefore, the "National Medium-and-Long-Term Education Reform and Development Plan Outline (2010-2020)" has taken "enhancing the constitution construction and improving the governance model" as the basic request to construct the modern university system. The researches on the constitution of colleges and universities are blooming, however, many of them are inclined in the study on the constitution of public colleges and universities, while few of them paid great attention on the constitution of private colleges and universities. The private university education is an indispensable part of the higher education in China, so it is necessary to study the intrinsic value, the predicament and the realization way of the construction of the constitution of the private colleges and universities, so as to lay a solid theoretical basis for the full implementation of the system construction of modern private colleges and universities in China.
\end{abstract}

\section{The Intrinsic Value of the Constitution Construction of Private Colleges and Universities}

The constitution of university is a prerequisite for the legal establishment of private colleges and universities, and is also the theoretical support for the relevant work carried out by the management and supervision departments in China, as well as a powerful guarantee of self-governance of universities. At present, China's private colleges and universities are undergoing a profound transformation; some provinces have completely classified some private colleges and universities with original third-tier-university qualification into second-tier-universities and abolished the third-tier-university enrollment system. The education reform of college entrance examination is not only an opportunity but also a challenge for private colleges and universities. As a result, these private colleges and universities should carry out the construction of constitution to promote the schooling according to the rule of law and the running of schools according to standards, so as to finally realize the grand blueprint of sustainable development of private colleges and universities. 
The legal basis to ensure private colleges and universities runs according to the law. Running the school according to law is the concrete practice of governing the country in accordance with the law in the management of the colleges and universities, and it is the only way for the private colleges and universities to carry out the spirit of Fourth Plenary Session of 18th CCCPC, grasp the socialist direction for schooling and running and carry out the comprehensive reform of the private colleges and universities. The constitution of colleges and universities provides the legal guarantee for the normal development of teaching and researching practices. As the important role played by the "Constitution" in the society, the core content of the constitution of colleges and universities covers the relationship between the rights and obligations of university students and teachers, clears the rights and responsibilities regulations between the various legal bodies in universities, and ensures the smooth running of daily works of private colleges and universities, it is the legal basis ensure the running of schools according to the law. To the outside of private colleges and universities, the constitution is the source and basis for governments in their administration on private colleges and universities, as well as the "magic spell" of social supervision. From the aspect of internal institutions of private colleges and universities, the constitution of colleges and universities is also the legal source to clear the internal operating mechanism of universities, to ensure the clear responsibility of each internal body, to establish the independent decision-making power and executive power of private universities, and to clarify the development idea of independent running of private universities.

The important medium of constructing a modern university system. The 40th article of "The National Medium-and-Long-Term Education Reform and Development Plan Outline" proposed "strengthening the constitution construction, all colleges and universities must custom their own constitutions according to the legal rules and regulations and govern the school according to the constitution request". Therefore, the constitution, as an important part of modern university system, is also the main medium of modern university system. From the perspective of social governance, the core of constructing modern university system is to highlight the independent running of colleges and universities and to break the academic barriers based on the rule of law. This is faced with how to deal with the interests between universities and governments, between universities and the society and among the internal management institutions of universities. The constitution of colleges and universities, by relying on the concept of rule of law, needs to clarify the rights and obligations between the various bodies of rights and interests, and needs to allow the relevant responsible persons to form a balance of interest, so that the colleges and universities can be running on a high degree of autonomy and academic freedom basis, so as to realize the independent running of colleges and universities and to highlight the essential connotation of modern university system. The constitution of private colleges and universities is the inner demand of constructing the scientific system of modern universities, and is also the cornerstone of the law for outlining the modern university system, and possesses a leading role in the idea of the modern university system construction for private colleges and universities.

The main ways for the independent running of private colleges and universities. The Education Law states that schools and relevant educational institutions have the right to operate independently in accordance with the constitution. "Non-state Education Promotion Law of the PRC" pointed out that the private institutions and public institutions are under the same social status in the law, the State expressly encourages private institutions to carry out schooling activities independently. The constitutions of universities, as red-head files that can be relied on by universities to carry out schooling activities, not only makes a clear stipulation for the relationship between all internal or external bodies of interests relevant to colleges and universities, but also provide materials for setting the goal of running a school and designing its management process. It provides guidance for the independent running mode and operation processes of universities and makes the university running become highly-efficient and evidence-based. ${ }^{[1]}$ At the same time, with the expansion of the independent running of private colleges and universities, it is necessary to make their rights, responsibilities and obligations should be based on the position and principle of "must not do anything unless it is mandated by the law", to prevent these universities to fall into the 
quagmire of "doing anything which are not prohibited by the law". The constitution of the universities ensures the independent running of the private colleges and universities, but also gives some checks and balances to these private universities, so that the private colleges and universities should know their rights and obligations under the guidance of the university constitution.

The solid backing for private colleges and universities to strengthen their external exchange and cooperation. Only by allowing the society to participate in the management of school's teaching, scientific research, employment and other aspects, these schools can meet the demand and expectation of the society on their trained talents and can adjust the training mode, change the development idea, so as to build an effective mechanism to make the ideal of running a private university be in line with the needs of social development. The university constitution can ensure that the interactive mode and communication way between the private colleges and China's socialist market economy become more systematic, institutionalized and standardized, so as to effectively promote the realization of the idea to share the resources between the private universities and social institutions, and create a new model to allow the society to participate in the management of private universities. In other words, the university constitution is the glue that integrates the social supervision and enhances the development of private universities. To allow the society to participate in the management of private colleges and universities, it will strengthen the strength of management, so as to build an effective platform between talent training and social needs and form an effective docking channel and communication mechanism between private universities and social employing units.

\section{The Realistic Predicament in the Construction of the Constitution of Private Colleges and Universities}

The drafting subject of the constitution is ambiguous. The clarification of the drafting subject of the constitution is the core link of drafting the constitution. The 9th article of "provisional regulations on the registration and management of private non-enterprise units" expressly stated that the organizer shall provide documents such as "draft of constitution" to the Registration and Approval Departments for the establishment of non-enterprise private institutions. The 14th article of "Non-state Education Promotion Law" also publicly stipulates that the organizer shall provide and submit the "school constitution" and other formalities to the relevant audit and approval units for the establishment of private universities. ${ }^{[2]}$ Thus, the drafting body of the private universities should be organizer. However, most of the drafting subject of the constitution of private colleges and universities is not clear: the drafting of the constitution of some private colleges and universities is actually the responsibility of organizers, but the drafting responsibility of some private universities' constitution is grasped by Staff Representative Assembly and the drafting responsibility of a small number of private universities' constitution is entrusted to the Teaching Affairs Management Agencies.

The constitution highlights commonness but lacks individuality. The intended goal of customization of the university constitution should clarify the outline and specific contents of the constitution to a certain extent. However, in actual practice, the constitution is only used as the legal basis of private colleges and universities to run a school or to undergo re-audit for school qualification, rather than being used as a reference blueprint for the reform and development of the teaching and research of private colleges and universities. Therefore, the customization of private colleges and universities' constitution is generally produced by filling the blanks in the "Model Constitution" prescribed and produced by the Local Education Administration Department. ${ }^{\text {[3] }}$ Therefore, the constitutions of many private colleges and universities have a high homogeneity, which imperceptibly make the development goal of running private universities become highly "homogeneous". In essence, it reveals that the cognition and practice of the private colleges and universities for constructing a modern college system should be improved, and they lack the active willingness and conscious behavior to integrate the constitution construction into the modern university system construction. 
The implementation of the constitution is just passable and formalistic. The constitution is the bridge and the link between various bodies of interests to build a university, including the school, the government and the society, and it is also a premise of the internal rules of the school. According to the relevant laws and regulations, the prerequisite for the establishment of private colleges and universities is to clearly custom the university constitution and to determine the relations between investors, teachers and regulators. If the customized constitution does not conform to the relevant provisions and regulations, it will not pass the audit. As a result, many local education departments drafted and promulgated the Model of the Constitution of Private University (hereinafter referred to as the "constitution model"), such as Guangzhou, Hubei, Hunan, Anhui, Liaoning and other provinces and municipalities. And these departments require private universities "must cover the core content of the constitution model" in the process of constitution customization, Thus, from the perspective of formality, private colleges and universities indeed have constructed their "own constitutions". However, the majority of private colleges and universities merely constructed their own constitutions as the bargaining chips for the establishment of school and passing the annual auditing, rather than considering the constitution as the theoretical source of running a university. The constitution is only a formalistic "reference" which will never be tested by practice, and will never play its important role as the "Constitution" of universities.

\section{The Realization Way of the Construction of the Constitution of Private Colleges and Universities}

Clarify the responsibility subject of the constitution. The subject clarification should determine who are responsible for the drafting and the late revision of the constitution. According to the relevant policies, laws and regulations, it is pointed out that the responsibility subject for the initial constitution drafting should belong to organizer of the private university. Since the beginning date of the registration and establishment of the university, the subject responsible for the late revision of the constitution should clearly cover the organizer, its agents, the principal of private universities, teaching administrators and logistic service personnel and other various departments of rights and interests of the school (including the Board or the Council of the private university, etc.) ${ }^{[4]}$ rather than merely covering the organizer who originally constructed the constitution, so as to cover the interest demands of all parties to the school. Through this way, the constitution can finally embody the scientific nature, comprehensiveness and effectiveness that a constitution is supposed to possess, so as to avoid that the constitution will become a protective umbrella that only protects small groups in the private colleges and universities.

Deeply excavate the self-characteristics and cultural ideas of universities to create an individualized constitution. The focus of the constitution of university is to highlight the idea of the undertaking of the school. What kind of academic research and campus culture atmosphere that the school wants to create will lead to the corresponding management mode and teaching means. The constitution of private colleges and universities should be based on deep digging and absorption of their own academic ideas and characteristics of campus culture, so as to create unique styles and characteristics and express and convey an individualized and vivid concept. Therefore, in the drafting of the constitution of a university, the drafter not only should systematically and comprehensively cover the core content of relevant rules and regulations, but also should not neglect the essential templates and examples in the constitution, so as to ensure the scientific, objective and reasonable generality of it. And the theoretical construction should be good at matching the real situation and environment, as far as possible reflects the local characteristics and cultural atmosphere of this area, this region and the school area, summarizes, concludes and condenses the individualized teaching mode, teaching goal, campus culture and teaching idea to be integrated as the essence and soul of the content of customized constitution and to be reflected into the each line of the constitution. Once the constitution of a private university is customized through the scientific model and process, it will possess a distinctive and personalized feature and the characteristics and effectiveness of exclusive customization. 
Strengthen the review and supervision of the content of the constitution. First, at the establishment of private colleges and universities, the audit focus should be put on the content of the constitution. The constitution is not only one of the necessary formalities required for the establishment of private colleges and universities, but also a standard guide for the daily teaching of these schools. The main focus of the audit should be put on whether the theoretical source of the constitution is comprehensive, whether the contents of the constitution are detailed, whether the format conforms to the stipulations, whether the provisions are comprehensive and whether the late revision mechanism is reasonable and lawful. A comprehensive analysis should be performed from the aspects of management personnel, professional standards and work energy. In the process of evaluating a private university's constitution, some methods such as Delphi method can be used and some experts and scholars in the relevant field can be invited to conduct the audit evaluation, so as to make the audit full of objectivity, authority and specialization.

Secondly, for the final key link of the constitution, i.e. the implementation process, it should increase monitoring and management efforts to ensure that the university constitution is effectively implemented. It should continuously strengthen the supervision and assessment on the implementation effect of the constitution of the private colleges and universities, and regard them as the "highlight" of the audit work for private colleges and universities. At the same time, the implementation attitude and effect of the constitution of the private colleges and universities should be used as an important reference for Education Departments to decide the rewards and punishments on these schools. For private universities with non-implementation or insufficient behavior of constitution, in annual Education Departments' evaluation, assessment, project funding assistance and allocation of university enrollment program indicators, these universities can be disqualified by one-vote veto, so as to avoid tolerating and condoning the germination and occurrence of such noncompliance events. The relevant audit and approval authorities should order the private colleges and universities and their school affairs management departments to follow their individualized constitution and absorb and introduce some effective information dissemination and monitoring tools of the current large data era, such as Micro-media and self the media and utilize the short, frequent, fast and other advantages of these supervisory means to share and push their individualized constitution on the exclusive platform of audience groups via the means of microblogging, WeChat, QQ and network public account and other media. The colleges and universities should set up an online platform to track the preparation and implementation of university constitution and to positively interact with members of the society, and to openly and modestly receive the comments and recommendations of the public on the promulgation and implementation effect of university constitution, so as to make a timely feedback, modification and improvement and meet the supervision expectations of the public and get an all-round, multi-angle, objective and impartial effect.

\section{Acknowledgements}

This paper is for The project of "12th Five-Year" planning of Education Science (No. 2011A128) by Hubei Provincial Department of Education.

\section{References}

[1] Ma Luting. Pondering after the full start of the constitution preparation works of colleges and universities [J]. China Higher Education Research, 2012 (3): 1-7.

[2] Chen Lipeng, et al. Research on university constitution - Exploration on theory and practice [M]. Beijing: Beijing Normal University Press, 2013.

[3] Li Yuanyuan. Improvement of the constitution of modern universities, deepening the reform of governance structure [N]. China Education Daily, 2012-03-05 (5).

[4] Pan Yilin, Lin Huilian. University constitution: a guarantee for building a harmonious university system [J]. 2008 (1): 44-47. 